\title{
The Demography of Employment and Unemployment in Egypt from 2002 to 2012
}

\author{
By Mohamed El Khouli*
}

\begin{abstract}
This study traces the trends in both employment and unemployment in Egypt on the basis of some demographic variables. It also studies the gender gap in employment and unemployment in order to highlight the status of females in Egypt. Ultimately, it will depend on data issued by official statistical authorities on the national level for the target period (2002-2012). The study concludes that the unemployment rate among those with higher education, especially females, reached its maximum in 2012. There were also significant differences in the rates between males and females and residents of urban and rural areas, as unemployment in urban areas was higher than in rural. The unemployed males in urban areas and the male graduates of theoretical faculties experienced the highest increase in unemployment during the period under analysis. This study recommends the adoption of national projects of employment in collaboration with the private sector to limit the gender gap and reinforce the participation of youth in the labor force. Moreover, it hopes to attract the attention of officials and provide motivation for them to develop unemployment protection plans and policies to enhance the economic status of youth and women in Egypt.
\end{abstract}

Keywords: Arab countries, Demography of employment, Demography of unemployment, Egypt, Females

\section{Background}

The issue of unemployment has been one of the most pressing problems for many countries over the recent decades. Nowadays, it tops the list of priorities regarding development programs especially in countries where gender gap constitutes a major social problem. Internationally, most of the developing as well as the developed economies confront a worsening youth employment crisis. Young people are three times more likely to be unemployed than adults. Over 75 million young workers worldwide are "hunting" for work. The statistical office of the European Union declared that the Euro area unemployment rate was $12.0 \%$ in 2013 , while the youth unemployment rate was $23.7 \%$ (Eurostat 2013). Based on this hard evidence, the International Labor Organization (ILO) has warned that the youth is facing a dangerous mix of high unemployment, particularly in the developing world (Mirkin 2013). The Arab region generally stands out in terms of its overall unemployment problem that exceeded $10 \%$ in 2011 . The youth unemployment rate in this region rose sharply in the wake of the Arab Spring, reaching the level of 27\% in 2012, i.e. the highest in the world and twice the global rate for youth. ILO showed that the youth unemployment rate was the highest among other

${ }^{*}$ Assistant Professor, Sadat Academy for Management Science, Egypt. 
subgroups, exceeding the total employment rate by about three times in the Arab countries. The World Bank also showed that the unemployment rate among the youth ranges between $15 \%$ and $25 \%$ in many countries of the Middle East, i.e. a quarter of the young men cannot find jobs (Andreson 2013). On the other hand, the Arab region's labor participation rates are amongst the lowest worldwide, currently being at the level of 35\% vs. global average of $52 \%$ (Khalifa 2013). Furthermore, according to unemployment statistics the age group between 20 and 24 years faced the highest unemployment rate in the Arab region (ESCWA 2005).

The League of Arab States indicated that the share of employed women in the Arab region does not exceed $20 \%$ of the total industrial employment, being lower than the relevant international share which is $40 \%$. The World Bank also showed that $75 \%$ of the Arab women are jobless (Andreson 2013). Moreover, there are also differences in unemployment indicators across gender (LAS 2013 ) with the unemployment rate for young males being estimated at $24.5 \%$ in 2012 and the female one being at the much higher level of $42.6 \%$ (ILO 2013). Obviously, those figures are strong indicators of discrimination and gender-based exclusion taking place in the Arab region. Regarding this sensitive issue, the World Bank urges job creation for women and youth in the Arab countries.

Egypt has recently experienced a rapid and substantial aggravation of the socio-economic adversities related to unemployment in particular among the youth. The Egyptian youth unemployment rate takes the third place among other Arab countries reaching $31 \%$ in 2013 according to the Human Development Report for Arab states. Unemployment is treated as a national issue of the highest priority by the Egyptian government which strives to find appropriate solutions, encouraging initiatives and studies that address this issue in depth. Besides, the private sector in Egypt, being accountable for $73 \%$ of employment, has shrunk in the wake of the Arab revolution on the $25^{\text {th }}$ of January 2011, thus slowing down its job creation potential. Twenty-seven percent of the labor force ( 26 million workers) is employed in the public sector, just $22 \%$ of them being women (AfDB 2013).

Against the backdrop of deteriorating economic conditions employment creation stagnated. The Central Agency for Public Mobilization and Statistics in Egypt (CAPMAS 2013) reported that unemployment rate had climbed to $13.4 \%$ in the third quarter of 2013 compared to $13.3 \%$ in the third quarter, $12.5 \%$ in 2012 , and $8.9 \%$ in 2011 . The employment rate of males had also increased to $9.9 \%$ in the third quarter of 2013 compared to $9.1 \%$ in 2012 while, the employment rate of females has climbed to $25.1 \%$ in the third quarter of 2013 compared to $24 \%$ in 2012 (AfDB 2012). In the context of the broad consensus about the adverse economic, social and political implications of this problem, the present study focuses on the existing gap in the employment and unemployment indicators across gender, in its attempt to provide evidence that some demographic subgroups are more vulnerable to the risk of unemployment than others. To further support the argument that inequality constitutes a rising social hazard in Egypt, it examines the relative differences between males and 
females under the scope of specific demographic characteristics, as well as the connections between demographic factors and the increasing unemployment rate. The ultimate objective is to define a new set of indicators which could help policymakers to determine the appropriate treatment for eliminating both the gender gap and unemployment as well as enhance the efficiency and effectiveness of policies and plans to be developed in the coming years.

\section{The Problem of the Study}

Over the next ten years, through 2020, at least 30 million more young people will join the workforce as a result of the increasing growth in the working-age population in many countries including Egypt (Martin 2009). During the past period from 2011 to 2013, UNICEF (2013) also pointed out that Egypt suffered from sluggish economic performance and growing unemployment rates. Moreover, in the past two years, Egypt has suffered from labor strikes, deteriorating security conditions and demonstrations almost on a daily basis, evidently, this social upheaval posed significant challenges as well as restrictions in the adoption of clear employment policies for limiting unemployment for all the consecutive governments of the period. In addition, the process of establishing more national projects to encourage foreign investment is still limited. These factors jointly had a sharp impact both on the already high unemployment rate and the widening gender gap among the employed as well as the unemployed. The youth unemployment rate in Egypt amounted to $13.4 \%$ in 2013 being higher than the global unemployment rate which amounted to approximately $12.6 \%$ and $12.4 \%$ in 2013 and 2012 respectively (ILO 2013). Women's participation in the labor market in Egypt is low, with the gender gap being a result of employment discrimination on various grounds (ITUC 2011).

Although the creation of productive employment for the youth has recently climbed to the top of policy concerns in Egypt, the rising unemployment trends are still worrisome. Specifically, past demographic growth is now translating into increasing numbers of young job seekers having to deal with discrimination causing a large gender gap (Assaad et al. 2000). This poses challenges and obstacles to Egyptian authorities as well as to policy makers in terms of providing the necessary funds to conduct research valuable for coming up with effective solutions. The present study will engage in a detailed analysis of the trending patterns of both unemployment and employment as well as the evolution of the gender gap during 2002-2012 in Egypt. It will also attempt to evaluate the policies implemented to reduce unemployment taking under consideration the Egyptian special circumstances. Hence, the study is centered around the four following research questions:

- How could the trend (in percentages) followed by the unemployment and employment during the time period 2002-2012 in Egypt be specified? 
- Were there any relative differences in the unemployment rates across gender and region of residence during the period 2002-2012?

- Were there any relative differences in the unemployment rates across gender and educational status as well as economic activity in 2012?

- Which were the demographic or social subgroups that experienced the highest increase in unemployment?

- What are the demographic characteristics associated to higher probabilities of unemployment?

\section{Justification}

The policy relevance and contribution of this study could stems from the following points:

- The ILO, through its regional office for Africa, had warned that in 2013, North Africa, including Egypt, would still remain among the regions with the highest unemployment rates and gender gaps.

- The lack of studies focusing on emerging trends in both unemployment and employment in different periods of time.

- The decision makers' keenness to support future plans or policies targeting the high rates of unemployment as well as the gender gap in employment opportunities.

- Pledges of the Egyptian government and public authorities towards seeking an appropriate solution to solve the problem of youth unemployment.

\section{The Objectives of the Study}

The study's main objective is to contribute to the design of a policy mixture effective in dealing with the high levels unemployment in Egypt as well as the gender gap by enhancing the opportunities of gender equality and supporting the status of women in the labor market. The sub-objectives are categorized as follows:

- To gain in-depth understanding of the percentage changes in unemployment and employment rates during the time period 2002-2012 in Egypt across gender.

- To examine the relative differences in unemployment rate across gender and region of residence based on the data drawn from the period 2002-2012.

- To determine the relative differences in employment status and conditions between males and females by occupational sector as well as in unemployment and employment patterns according to educational status in 2012. 
- To determine whether demographic or social factors predict unemployment in Egypt based on the data available from the labor force statistics office for the period 2002-2012.

\section{Literature Review}

Rapid population growth and the phenomenon of gender inequality inevitably lead to high rates of unemployment unevenly balanced between males and females, thus it is considered to be a concern on the economic, social, educational and security level. The study of Goulding focused on gender equality within national employment policies (Goulding 2013). Furthermore, in an attempt to promote gender equality, the Gender Equality and Diversity Branch of ILO have outlined some key areas regarding the gender-related roles within the world of work (GED 2013). The study of Bernard (2013) focused on the gap between the unemployment rates of youth and adults and proved that the youth unemployment rate was the highest.

Other studies analyzed the trends of employment and unemployment during different time periods and regions. The study of Ghose discussed trends of employment and labor market conditions in China during the period from 1990 to 2002 (Ghose 2005). Another study examined the nature of Greek unemployment demonstrating cross-sectional dependence among Greek regions (Bakas and Papapetrou 2012). Yet another was interested in studying the major trends of employment in the light of the changes in demographic characteristics of the Chinese population (Meiyan and Yang 2010). The study of Visaria analyzed youth unemployment trends in India (Visaria 1998). Bell and Blanchflower (2010) focused on various age groups in examining the unemployment rates in developed countries. The study of Cai and Chan (2009) examined the impact of the global economic crisis on the job security of urban workers in China during 2008-2009 as well as its overall repercussions for the Chinese economy. A study of Fougère et al. (2006) examined the influence of unemployment on crimes and violence in France.

Some studies have also studied the patterns of the female participation in the labor market nationally and internationally, such as the study of Assaad et al. (2000). They found that educated young women are more adversely affected than their male counterparts by high unemployment rates in the private sector. Another study showed that the women's share in the labor market in the Middle East and North Africa (MENA) is estimated at only $2.25 \%$, which is considered one of the lowest rates in the world (Andreson 2013). Some studies have put forward solutions to the problem of unemployment, such as the study of Radwan (2002), which pointed that the implementation of unconventional policies and the creation of labor market institutions are necessary to achieve the objective of full employment in Egypt. This study concludes that the three major components of an effective policy reform are summed up in the following three points: expansionary macroeconomic policy, enhancement of workers' productivity and reform of the civil service (Radwan 2002). The study of Fawzy showed that the real danger of unemployment lies in the fact 
that it reflects low and inefficient levels of investment and growth (Fawzy 2002). Also, the study by Fougère et al. (2007) has suggested that training improves the matching process between jobseekers and firms in France. ElAgrody et al. (2010) showed that the most important factors contributing to the rising levels of unemployment are privatization and inflation.

Obviously, many studies have pointed out the problem of unemployment, especially among young people as well as the weakness of women's opportunities in the labor market. However, little attention has been given to the importance of demographic variables along with gender inequality as indispensable steps in the process of coming up with the right solutions to the unemployment problems. The recent studies centered on the Egyptian case have not address these aspects as well as the changing patterns in unemployment, employment and the gender gap. Our study will shed the light on all those aspects in an in-depth, detailed manner. As the present study suggests, the most important problems associated to unemployment could stem from the following factors, specifically in Egypt:

- widening the gender gap in employment and unemployment indicators;

- the limited number of job opportunities for young graduates especially in the light of their strong preferences to work as public servants;

- increase in the supply of labor without meeting the requirements and needs of the market either nationally or internationally;

- inadequacy of the policies and active labor market programs, in resolving the disparities between labor supply and demand.

Therefore, in the context of reviewing the problem of unemployment in Egypt, the current study will focus on the gender gap issue, as well as on the phenomenon of joblessness among women and youth in particular.

\section{Methodology}

The current study follows a quantitative approach, being based on descriptive statistics and explanatory techniques. It is of longitudinal nature as it statistically depends on time series data drawn from the 2002-2012 period, being available in a consistent and adequate form.

\section{Location}

The current study focuses on The Arab Republic of Egypt which from the northeast corner of Africa to the southwest corner of Asia. It is geographically bounded on the north by the Mediterranean Sea, on the east by Palestine and Israel, on the south by Sudan and on the west by Libya (Figure 1). The total area of the Arab Republic of Egypt amounts to nearly $1.010 .000 \mathrm{Km}^{2}$, while the populated area reaches $78,990 \mathrm{~km}^{2}$ representing $7.8 \%$ of the total area ${ }^{1}$.

\footnotetext{
${ }^{1}$ See: http://www.sis.gov.eg.
} 
Figure 1. Geographical Location of the Arab Republic of Egypt

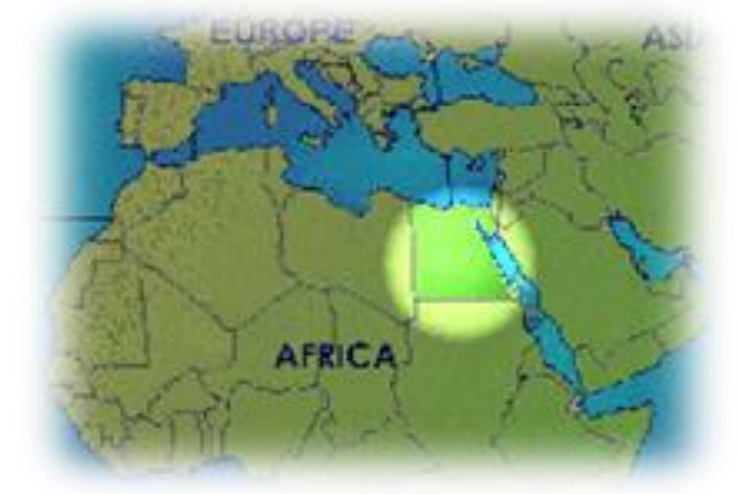

Source: http://www.sis.gov.eg.

\section{Demography}

The great majority of the Egyptian people live near the banks of the Nile River, an area of about 40,000 $\mathrm{Km}^{2}$, an area where the total extent of Egypt's arable land is concentrated. Egypt is the most populated country in the Middle East, and the third most populous in the African continent, with about 85 million inhabitants in 2014, according to the last population census statistics issued by the Central Agency for Public Mobilization and Statistics (CAPMAS 2014). Moreover, the males account for $51 \%$ of the total population according to 2006 census while females account for 49\%. 27.2 million Egyptians constitute the total of labor force, of whom $87 \%$ employed and $13.3 \%$ unemployed. Approximately 338,000 Egyptians joined the workforce during the third quarter of 2013 , of whom $57 \%$ males and $43 \%$ females. Over this period, the total unemployment rate was $13.4 \%$, the male rate was $9.95 \%$ while the relevant figure for women was $25.1 \%$. Figure 2 shows that the number of unemployed in Egypt was constantly increasing in line with the population growth rate during 2002-2012.

The population growth rate has an impact on increasing the number of the unemployed in Egypt as this growth results in labor supply shocks in an annual basis. The high population growth rate is considered one of the major impediments to economic development opportunities in Egypt. 
Figure 2. Number of Unemployed and Growth Rate of Population in Egypt

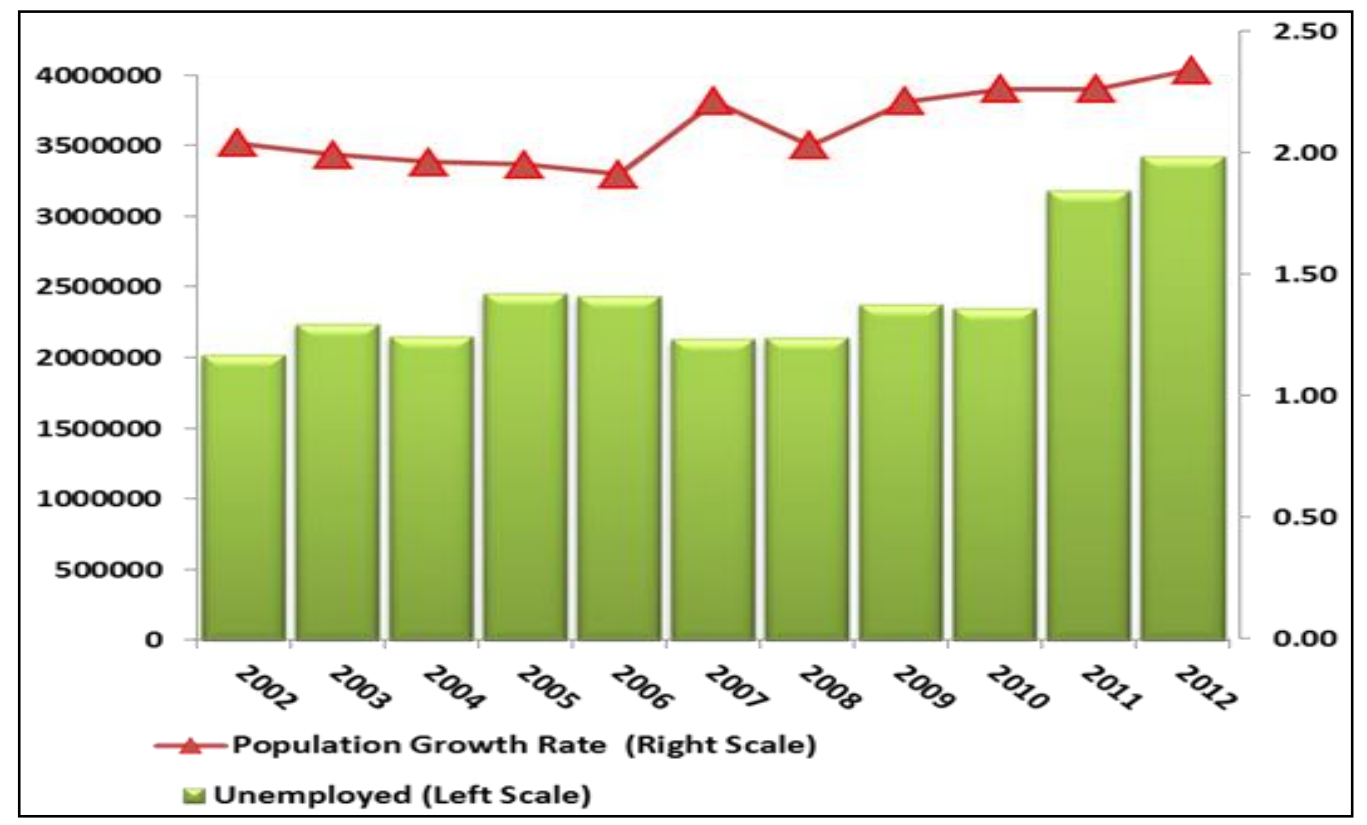

Source: Author's estimations.

\section{Delimitations and Limitations}

The current study has identified some boundaries and limitations in the process of conducting the statistical analysis; starting from the preparation stage, continuing with the data processing and finally, the results phase.

- Delimitations: The current study has exerted strenuous effort in order to gather the maximum amount of data and statistics related to unemployment published by the official Egyptian statistical services, especially CAPMAS, over the target time period of the study 20022012. The data collection was conducted in a manner consistent to the composition of a complete time series necessary for comprehensive examination and analysis.

- Limitations: The selection of specific demographic characteristics for the analysis of the determinants of employment and unemployment trends poses a significant restriction due to limited data availability. This leaves a lot of space for further studies and research projects to include other variables in the in-depth analysis of employment and unemployment trends. In the same manner, the gender gap patterns in employment and unemployment were analyzed on the basis of specific demographic variables that were available in the labor force surveys for the target period 2002-2012. 


\section{Statistical Analysis}

To provide comprehensive answers to the research questions posed in this study, appropriate statistical methods were used such as calculation of percentages $(\%)$ and frequencies $(f)$ as well as percentage changes in employment and unemployment rates in total and across gender. Additionally, a two-proportion test was used to determine the differences between the participation rates of males and females with regards to their educational status and occupational sector. A t-test of independent samples and a Mann-Whitney test was also used to determine the relative differences in the unemployment rates across gender and region of residence, i.e. between males and females and between rural and urban regions.

The tests were based on the following hypotheses:

$$
H_{0}: \quad d_{1}=d_{2}
$$

meaning that there is no significant difference in the unemployment rates across gender and region of residence, and

$$
H_{a}: \quad d_{1} \neq d_{2}
$$

indicating that there is a significant difference in the unemployment rates of the various subgroups.

Multiple regression analysis was also used to determine the most important demographic and social determinants of unemployment in Egypt during 2002-2012 attributed to certain background characteristics.

\section{Results and Discussion}

The results have revealed the percentage changes in unemployment and employment taking place in Egypt during 2002-2012 for both males and females (Table 1, in Appendix). Chart 1 (Appendix) shows the trends in unemployment and employment in parallel to the increase in total population and thus, the labor force. Although employment rates during the target period were higher than the unemployment ones, the Egyptian unemployment rates are higher compared to the global level of unemployment, which ranges approximately between 5-7\% according to the statistics of World Bank and ILO. Furthermore, Chart 1 shows that the unemployment rate in Egypt was constantly growing from 2010 to 2012, specifically, in the wake of the Egyptian revolution in 2011 (Chart 1, in Appendix). During that period a clear decline in the employment rate was also noted. This decrease could be attributed to the negative effects of the revolution on the tourism sector in particular. This situation shaped by the Arab spring requires the Egyptian decision-makers to continue resolving several multifaceted challenges emerging in the aftermath of this revolution.

A successful, multidimensional settlement on all the aspects and levels is a fundamental prerequisite for Egypt to turn around its economy to a sustainable and equitable growth path that would create jobs for the unemployed youth 
being a vast majority in the Egyptian society (AfDB 2012). As shown in Figure 3 , there were significant annual changes in the unemployment and employment rates during the period under analysis varying from negative to positive values, with the highest percentage change in the unemployment rate happening between 2010 and 2011 and amounting to approximately 35\%. This huge increase could be attributed to the revolution of $25^{\text {th }}$ January 2011 and its repercussions on the Egyptian economy. In addition, there was a decrease in the unemployment rate of around 12\% between 2007 and 2008, while during the same period, the highest percentage change in the employment rate reached the level of $7 \%$. The lowest percentage increase in the employment rate $(1 \%)$ took place between 2010 and 2011.

According to Chart 2 (Appendix), the total change in the number of the employed during 2002-2012 amounted to $32 \%$, increasing by $3 \%$ annually while the total change in the number of the unemployed amounted to $69 \%$, increasing by $7 \%$ per year.

Figure 3. Change Rate (\%) of Employment and Unemployment in Egypt (20022012)

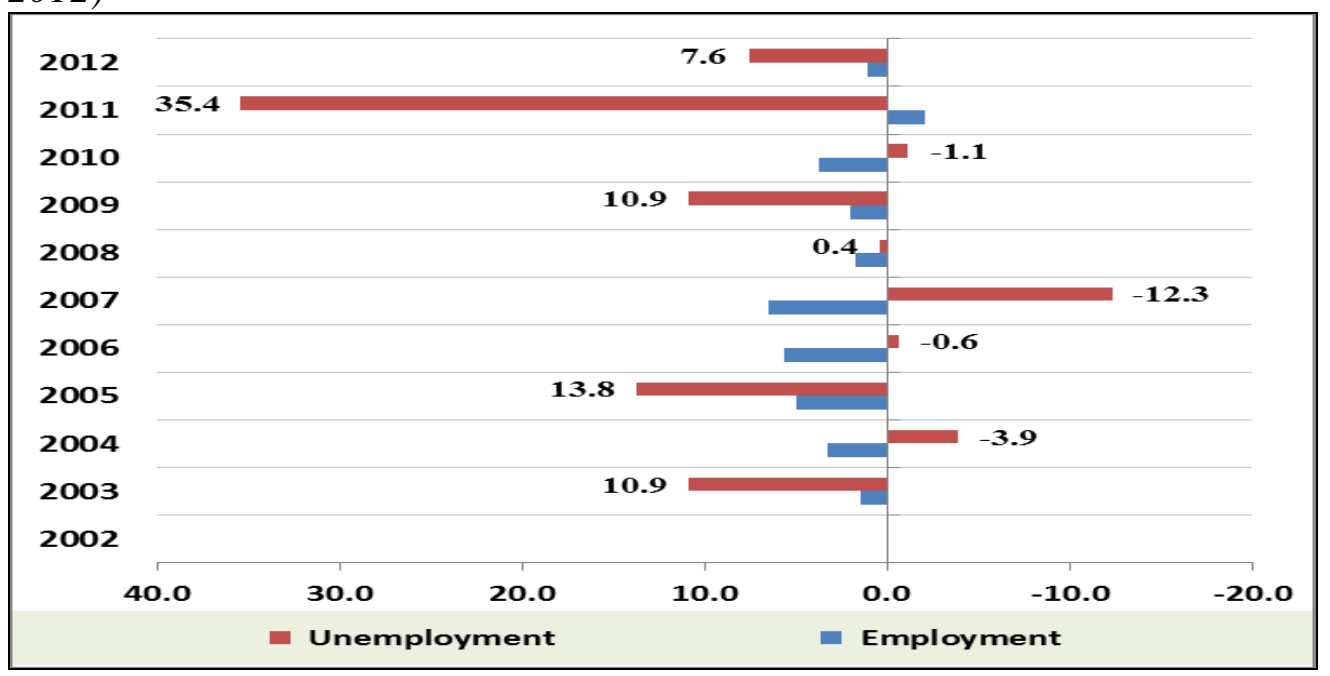

Source: Author's estimations.

Thus, the rate of the change in unemployment was equivalent to twice the change in employment in Egypt during 2002-2012 both in annual and total figures. Looking at Figure 4, it is also made clear that, despite a slight fluctuation in the pattern of the unemployment rate happening during 20102012, the highest increase in the number of the unemployed took place during this exact period. Evidently, the period is characterized by a continuous rise in the unemployment rate, reaching its highest level (13\%) in 2012. In Figure 4, it is also evident that a significant rise in the unemployment rates for both females and males, with them amounting to $24 \%$ and $9.3 \%$ respectively, took place in 2012. 
Figure 4. The Unemployment Rate in Egypt, 2002-2012, and Comparison to Some Developing Countries in 2012

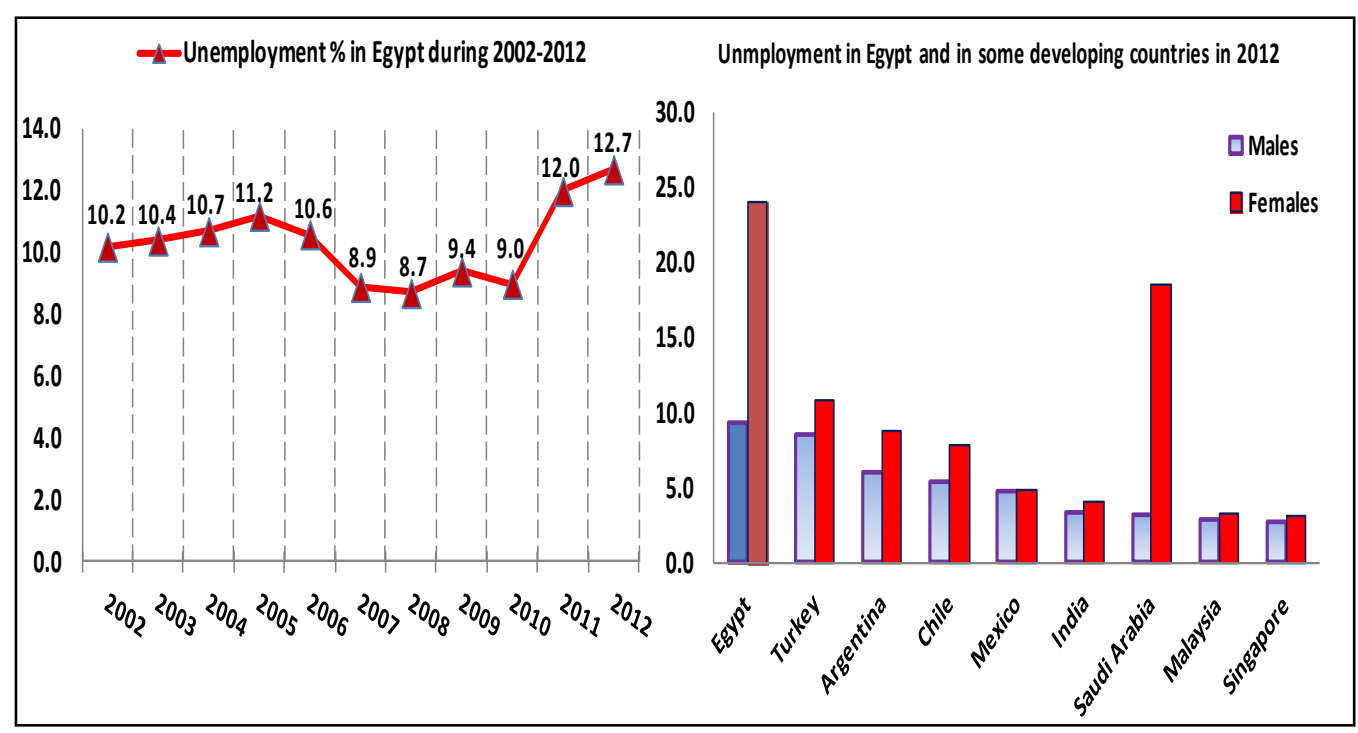

Source: World Development Indicators (http://worldbank.org).

In general, the unemployment rate among women was $24 \%$ in North Africa in the third quarter of 2012 including Egypt; i.e. more than double compared to the unemployment rate for men amounting to 9.1\% (AfDB 2013). Evidently, women experience higher unemployment compared to the case of men whether living in Egypt or in the surrounding region. Moreover, the study is based on the hypothesis that there exist relative differences between males and females with respect to the unemployment and employment trends that they experience in Egypt. According to Charts 3 and 4 (Appendix), the total change in the number of unemployed females (older than 15 years) during 2002-2012 amounted to $43 \%$, rising annually by $4 \%$, while for men the total change is estimated at the level of $97 \%$, rising $10 \%$ each year. This point contradicts the present study's expectations, according to which the growing trend in male unemployment (15+) was not anticipated to be almost equivalent to double the growth in female unemployment.

Similarly, the total change female employment $(15+)$, reaching the level of $41 \%$, is an increase, was rising by $4 \%$ per year, while male employment was increasing by about $3 \%$ annually, reaching the total level of $30 \%$ (Chart 3, in Appendix). This shows that the growing trend in employment among females is higher than the growth in male employment, which could be attributed to the keenness of state policies implemented in the light of the international interest for raising women's participation in the labor market during this period. In general, it should be noted here that women in the Arab region are not adequately represented in senior positions (LAS 2013).

As shown in Figure 5, the female participation in the labor market in Egypt was still considered low during 2002-2012 compared to the relevant rates in the other Arab countries as well as in the European and global level. This relatively low female participation poses one of the greatest challenges to 
the Egyptian government for boosting female participation in the coming period. Especially, ILO (2013) has indicated that although young women in Egypt and Jordan are attaining high levels of education, they still face difficulties in getting hired in occupations appropriate to their qualifications. This reflects the extent to which Egyptian women are striving to get the jobs opportunities meeting their aspirations and needs.

Figure 5. Labor Participation Rate of Females (15+) in Egypt Compared to International Levels (2002-2012)

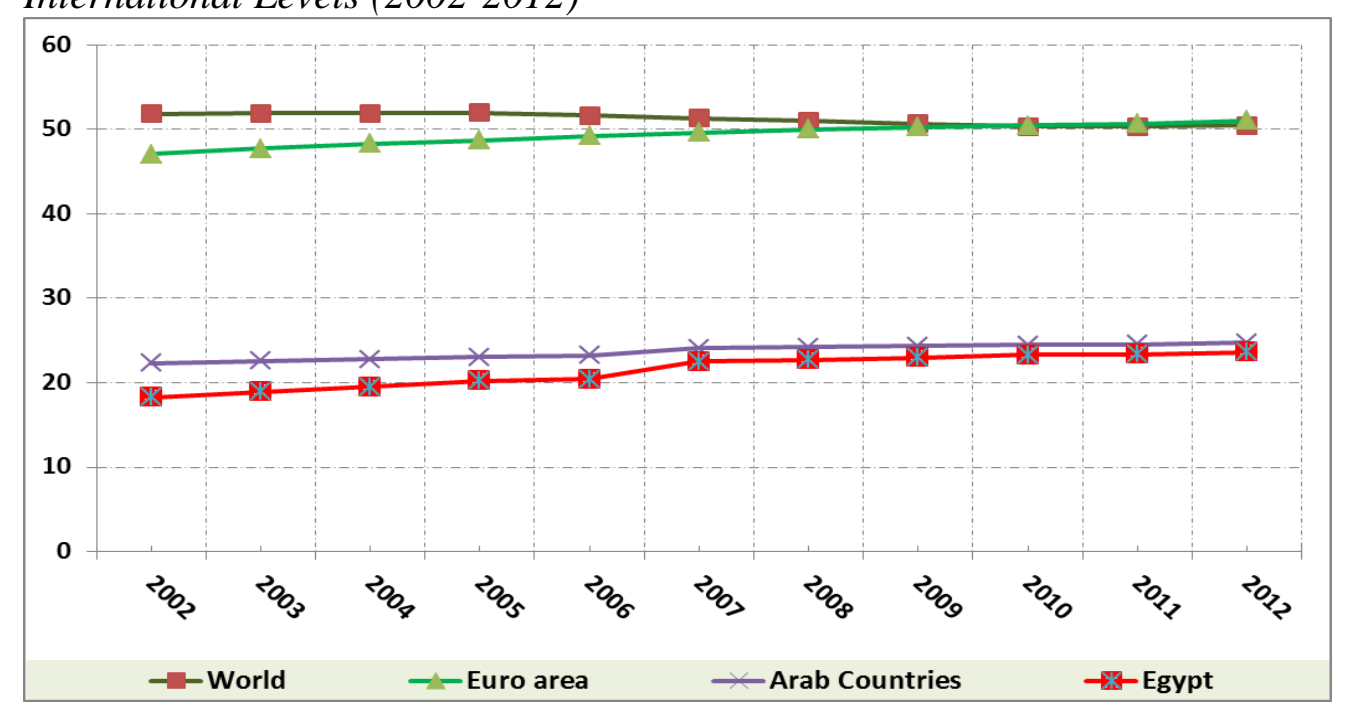

Source: Author's estimations.

Figure 6 shows the unemployment and employment rates for males and females separately during 2002-2012. It should be noted here that the female unemployment rate was higher than the male rate for each year of the period under analysis.

Consequently, it is shown that the unemployment rates for both males and females living in urban areas are higher than the relevant rates of those living in rural areas. This gap could be attributed to the nature of the Egyptian population in the rural communities, depending mainly on agricultural activity which is a more stable economic activity compared to the jobs in the industrial sector (Chart 5 \& Table 2, in Appendix).

For the purpose of conducting an in-depth analysis, the gender gap in Egypt should be examined in the light shed by the official figures of employment and unemployment patterns during 2002-2012. The present study uses tests of two proportions in order to examine the relative differences according to gender. The results indicate significant differences between the employment patterns of males and females in most economic activities, as shown in Table 3 (Appendix). The participation rates of Egyptian females in the education, health, social services, and agriculture sectors was higher than males' participation, whereas the opposite happened in the construction, manufacturing and transportation sectors. In those sectors, male participation was much higher than female participation potentially due to the fact that these 
activities require muscular effort and more working hours. As a matter of fact, the oonly sectors where the male and female participation was approximately the same were the creative and art activities, as well as the regional and international relations, while there were significant differences in the rest of the sectors (Table 3, in Appendix).

Figure 6. The Employment and Unemployment Rates in Egypt for Each Gender Separately (2002-2012)

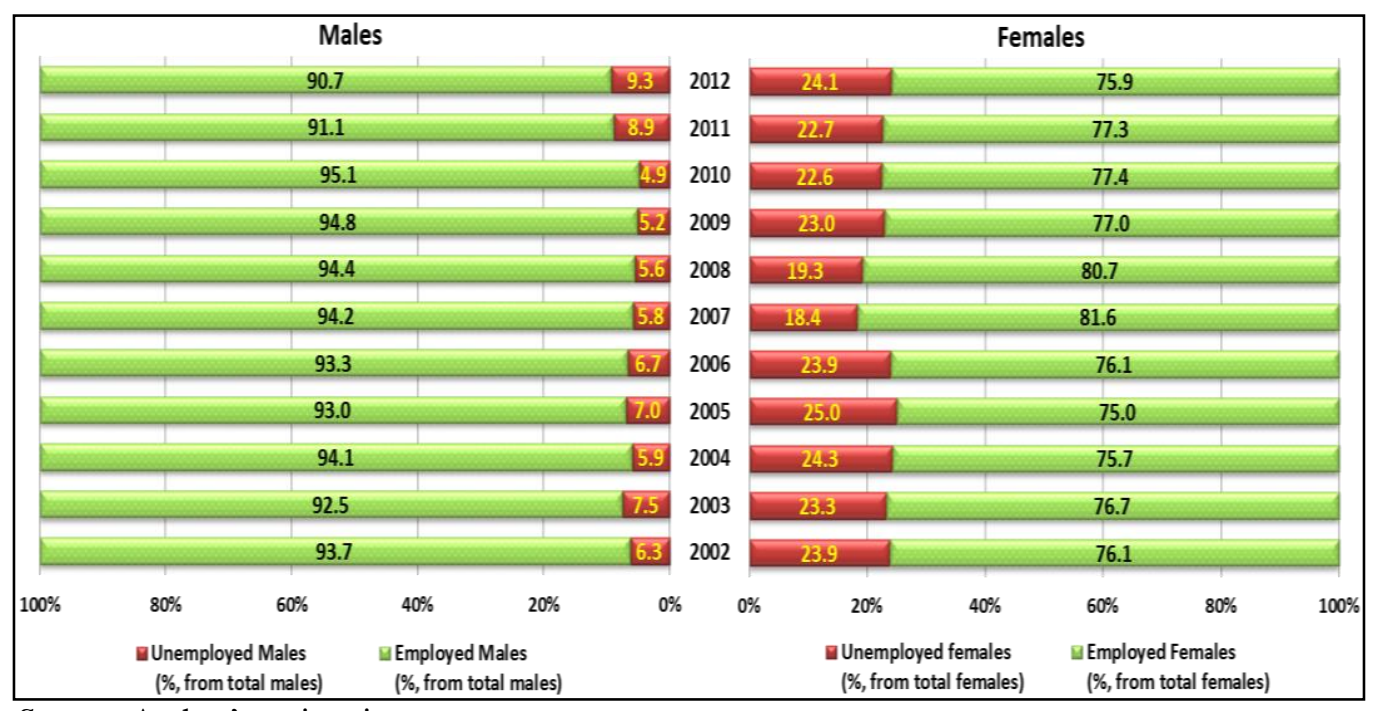

Source: Author's estimations.

Equally important is the fact that there were not any statistically significant differences between males and females, depending on their educational status both in the cases of the unemployed and employed (Table 4, in Appendix). In addition, the in the lower-education subgroup more men than women were unemployed, while among the highly educated group the unemployment was found to be higher among females than males and vice versa in the case of the employed. This result draws attention to the existing challenges of improving the status of educated women in Egypt, thereby necessitating the need to develop policies to ensure increased participation rates for women with higher education in the foreground of employment programs. In a similar manner, the findings of the t-test and the Mann-Whitney test presented in Table 1 showed that there were significant differences in unemployment rates across gender and region of residence, with the $p$-values in both tests being statistically significant at the $95 \%$ level. According to the tests, the female unemployment rate was higher than that faced by men, while unemployment in urban areas was higher than rural areas.

This is an indication that some specific demographic characteristics such as gender and region of residence could potentially influence unemployment among specific subgroups. It is thus required to take these background characteristics into account when adopting policies and plans to address the problem of unemployment in Egypt. As a result, policymakers in Egypt should have been working towards implementing more national scale projects that 
promote job-intensive growth for women, especially targeting the youth in urban areas, as an important step in the process of eliminating the negative impact of unemployment and low participation both on a social and security level. This is especially significant in light of the deterioration of the economic conditions in Egypt in the wake of the revolution. Attempts have been made by transitional governments to address the crisis, which was one of the main drivers for the youth to be engaged in the revolution of the $25^{\text {th }}$ January 2011.

Table 1. Relative Differences in Unemployment Rates, according to Gender and Residence, 2002-2012

\begin{tabular}{|c|c|c|c|c|c|}
\hline Test variable & \multicolumn{2}{|c|}{ Grouping Variables } & Mean & T-test & Mann-Whitney test \\
\hline \multirow{4}{*}{$\begin{array}{l}\text { Unemployment } \\
\text { Rates }\end{array}$} & \multirow{2}{*}{ Gender } & Males (15+) & $6.6 \%$ & \multirow{2}{*}{$21.185 *$} & \multirow{2}{*}{$-3.974 *$} \\
\hline & & Females $(15+)$ & $22.8 \%$ & & \\
\hline & \multirow{2}{*}{ Residence } & Urban (15+) & $18.4 \%$ & \multirow{2}{*}{$2.437 *$} & \multirow{2}{*}{$-2.680^{*}$} \\
\hline & & Rural (15+) & $11.8 \%$ & & \\
\hline
\end{tabular}

* Significant at the level of less than 0.05.

Source: Author's estimations.

On the basis of the Stepwise method, multiple regression analysis was used including the demographic, socioeconomic variables described in the context of the present study (Table 5, in Appendix). The statistical analysis concluded that the living in urban areas, the dependency ratio, the number of births and having gained a degree from the theoretical faculties for men are factors associated to higher unemployment. The findings presented in Table 5 (Appendix) also revealed that the $\mathrm{R}^{2}$ statistic amounted to 0.98 , which means that the variables included in the model are capable of explaining $98 \%$ of the total variance in the dependent variable. In addition, the variance analysis (ANOVA) has verified the accuracy of the proposed model by testing the goodness of fit of the baseline regression equation, resulting in an F-statistic equal to 91.99 and statistically significant at the $95 \%$ confidence level. This confirms the existence of a strong correlation between the independent variables and the dependent one in the following equation:

$$
\text { No.of unemployed }=(-45450.3)+(11.7) \cdot X_{1}+(372.1) \cdot X_{9}+(963.9) \cdot X_{13}+(0.14) \cdot X_{22}
$$

where $\mathrm{X}_{1}$ denotes births, $\mathrm{X}_{9}$ stands for the dependency rate, $\mathrm{X}_{13}$ denotes the male unemployment rate in urban areas and $\mathrm{X}_{22}$ the number of males graduates from theoretical faculties.

Based on the above equation, the share of the unemployed males living in urban areas had the highest, positive impact on the total number of the unemployed in Egypt during 2002-2012. The total number of the unemployed workers was also affected by the dependency rates, the number of births and finally, the number of the male graduates from theoretical faculties. Hence, it should be highlighted here that some demographic variables had indeed played a significant role in the rise of unemployment in Egypt at least during the period under analysis. Given these points, the demographic factors should be 
taken into account in the future plans. The unemployment rate continues to increase in parallel to the growth of the population in Egypt, as it is clear in Figure 2, with this phenomenon constituting an economically and socially strain for the economy of the country.

The most noticeable among these results is the effect of the share of unemployed men living in urban areas and the number of male graduates of theoretical faculties, indicating the existence of a clear imbalance in the higher levels of the educational system in Egypt and the weak quality of its outputs. On the other hand, the Economic and Social Commission for Western Africa (ESCWA) argues that high unemployment among the Arab youth could be associated to the ineffectiveness of the mechanisms of the labor market to absorb the rising labor supply (ESCWA 2005). Additionally, it appears that in the Egyptian labor market the vacancies are often filled by uneducated, lowskilled applicants, indicating a low quality, problematic matching taking place in the context of the market.

Evidently, there is a conflict taking place in the market reflected in the high rates of unemployment among people with higher education, especially females, compared to people with low education (Chart 6, in Appendix). This is due to the fact that highly educated people look for jobs that fit their qualifications and expectations about their career prospects, without getting satisfaction by jobs offering less than what they think they deserve. Figure 6 indicates that the share of unemployed graduates of theoretical faculties exceeds that of the unemployment graduates of practical faculties during 20022012, with the gap being high and constantly rising along with the total unemployment rate. This could be the main factor responsible for this inconsistency. However and despite the high number of higher education institutions operating in Egypt, the scarcity of state initiatives towards launching national projects for improving job opportunities for young people or for rehabilitating them is not a negligible issue. The education and training systems currently in place are evidently unable to provide the youth with skills required for meeting the needs of labor market (Ministry of Manpower and Immigration 2010). 
Figure 6. Number of Unemployed and Number of University Graduates in Egypt (2002-2012)

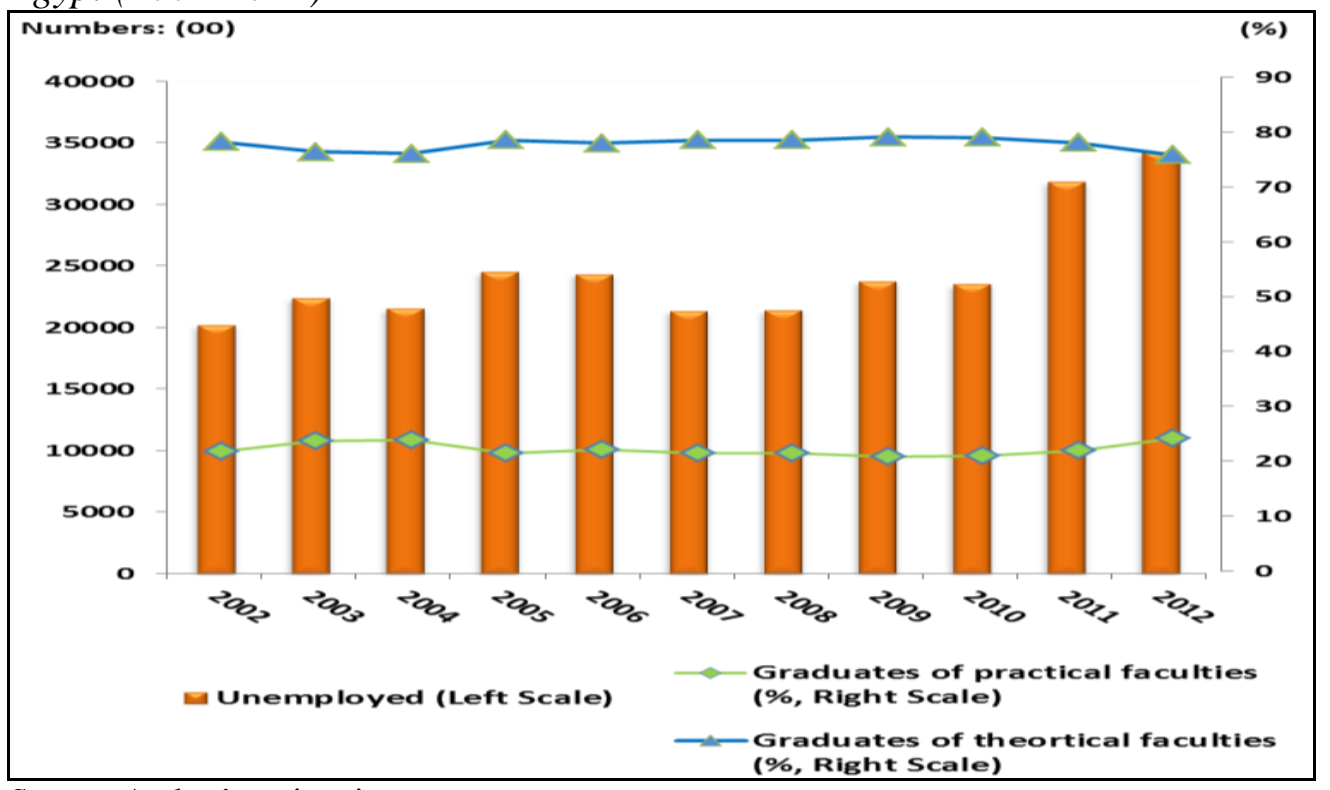

Source: Author's estimations.

Indeed, youth of higher education attainment are the most adversely affected by joblessness given that in this subgroup, only two out of ten actually manage to find a regular job (AfDB 2013). However, the review published by the Arab Human Development Report in 2013 demonstrated that highly educated people are affected by unemployment just as much as those with lower education (Mirkin 2013).

In summary, in order to face this imbalance we not only need to provide jobs for the youth, but there are also many challenges that should be taken under consideration including all aspects relevant to the unemployment issue such as the gender gap, the different prospects of graduates from different fields, the specific needs of the demand side in the labor market and the unfulfilled youth's desire to get jobs suitable to their scientific specialties. The expansion of the role of private sector's participation in addressing unemployment issues should also be taken into account.

\section{Recommendations}

- Policy makers should focus on addressing the interruptions in the matching process taking place in the labor market through enhancing graduates' skills on the basis of training and re-training programs. Training and career development centers should be established within universities in order to assist graduates in their attempt to gain the skills they need, as well as to provide them with bulletins about career services and jobs opportunities matching their qualifications on a regular basis. 
- A thorough review of the development and investment policies in Egypt, as well as the new opportunities of foreign investment is considered crucial. The deals should be awarded directly to the investment policies needed to achieve high and sustainable rates of investment which could in turn lead to new jobs and limited gender quality.

- $\quad$ The necessity of the government to adopt a multitude of policy initiatives and reforms to enhance employability on the basis of public employment services addressing the youth's needs.

- Improvement of the performance, productivity, relevance, and quality of education and training systems, in particular both the technical and higher educational systems.

- More active involvement of stakeholders, in particular institutions of the private sector, in the public discourse.

- Initiatives to support the professional integration of youth and females in the labor market.

- The government should take actions to improve women's participation in the workforce and take decisive steps for reducing the gender gap in both employment and wages.

- Reliance on the establishment of modern centers targeting the rehabilitation for graduates. For their effectiveness to be ensured, these centers should be subject to and evaluated by an independent body under the supervision of the state.

- International cooperation among neighboring countries on a regional level should be in the center of Egyptian state's attention. It is especially recommended to attract the countries around the Mediterranean Sea to invest in new collaborative projects and open new markets (e.g. duty free markets). Such a market, entitled as the "Mediterranean duty free market" could provide a sustainable solution to the countries that are exposed to high unemployment in neighboring regions around the Mediterranean, by boosting their national economies

- The expansion of grand investments on industrial and productivity projects in accordance with the priorities of the Egyptian economic strategy, including the ability to absorb the largest number of unemployed and graduates in the future, reduce the gender gap, accelerate economic growth, facilitate trade openness and reduce the rates of internal and external migration. Some ideas include to the development of a waterway through the Suez Canal, the establishment of investment projects in South and North Sinai and the opening of new, free markets and industrial zones to compete foreign goods. It is important to take into account the stability of the youth's families in the sites of such projects by providing all the appropriate infrastructure necessary for a decent living in terms of housing, malls, schools, universities, clubs, hospitals etc. 


\section{References}

AFDB-African Development Bank Group (2012) Economic Quarterly Review 1(June). Egypt: Egypt Country Office (EGFO).

AfDB-African Development Bank Group (2013) Economic Quarterly Review 3(April). Egypt: Egypt Country Office (EGFO).

Assaad R, El-Hamidi F, Ahmed AU (2000) The Determinants of Employment Status in Egypt. Food Consumption and Nutrition Division-FCND. Discussion Paper No. 88. Washington, USA: International Food Policy Research Institute-IFPRI.

Andreson I (2013) 75\% Arab Women Unemployed. Journal of Emirates 24|7. Available from: http://www.zawya.com/story/75_Arab_women_unemployedZA WYA20130417032631. [Accessed: 17 April 2013].

Bakas D, Papapetrou E (2012) Unemployment in Greece: Evidence from Greek Regions. Athens, Greece: Bank of Greece.

Bell D, Blanchflower D (2010) Youth Unemployment: Déjà Vu? IZA Discussion Paper No. 4705. Bonn, Germany: University of Stirling, CESifo, NBER and IZA.

Bernard A (2013) Unemployment Dynamics Among Canada's Youth. Economic Insights, Statistics Canada.

Cai F, Chan KW (2009) The Global Economic Crisis and Unemployment in China. Eurasian Geography and Economics 50(5).

CAPMAS-The Central Agency for Public Mobilization and Statistics (2014) Statistical Yearbook 2014. Available from: http://www.capmas.gov.eg/pdf/ Electronic\%20Static\%20Book2014//page/INTERFACE/home.htm.

CAPMAS-The Central Agency for Public Mobilization and Statistics (2013) Bulletin of Labor Force (July - Sep). Cairo, Egypt.

El-Agrody N, Othman A, Hassan M (2010) Economic Study of Unemployment in Egypt and Impacts on GDP. Egypt: National Research Centre.

Eurostat (2013) Statistics of the Statistical Office of the European Union.

ESCWA-Economic and Social Commission for Western Asia (2005) Demographic Window of Opportunity for Development in the Arab Countries. Population and Development Report ( $2^{\text {nd }}$ issue). New York: United Nations.

Fawzy S (2002) Investment Policies and the Unemployment Problem in Egypt. Working Paper No. 68. Egypt: The Egyptian Center for Economic Studies.

Fougère D, Kramarz F, Pouget J (2006) Youth Unemployment and Crime in France. IZA Discussion Paper No. 2009. France: Institute for the Study of Labor.

Fougère D, Crépon B, Ferracci M (2007) Training the Unemployed in France: How Does It Affect Unemployment Duration and Recurrence?. France: Institute for the Study of Labor.

GED-Gender, Equality and Diversity Branch (2013) Men and Masculinities: Promoting Gender Equality in the World of Work. Bureau for Gender Equality. International Labor Organization.

Ghose AK (2005) Employment in China: Recent Trends and Future Challenges. Employment Analysis Unit. Strategy Department.

Goulding K (2013) Gender Dimensions of National Employment Policies: A 24Country Study. Bureau for Gender Equality. Available from: http://www.ilo.org /gender/.

ILO-International Labor Organization (2013) Global Employment Trends for Youth 2013: A Generation at Risk. Geneva: International Labor Organization.

ILO-International Labor Organization (2013) Global Unemployment Rising AgainWhat About Africa. Ethiopia: International Labor Organization: Regional Office for Africa. 
ITUC-International Trade Union Confederation (2011) Internationality Recognized Core Labor Standards in Egypt. Report for the WTO General Council Review of the Trade Policies of Egypt.

LAS-League of Arab States (2013) Arab Report for the Millennium Development Goals. Facing the Challenges and Look Beyond 2015.

Khalifa D (2013) E4E Initiative for Arab Youth. International Finance Corporation (IFC). Available from: http://www.e4earabyouth.com/.

Martin I (2009) Youth Employment in Arab Mediterranean Countries: The Key to the Future. Madrid, Spain: European Institute of the Mediterranean (EIMed).

Meiyan W, Yang DU (2010) Demographic Ageing and Employment in China. Employment Working Paper No. 57. Geneva: International Labor Organization.

Mirkin B (2013) Arab Spring: Demographics in a Region in Transition. Arab Human Development Report. United Nation Development Programme: Regional Bureau for Arab States.

Ministry of Manpower and Immigration (2010) Summary of the National Plan for Youth Employment. Egypt: ILO Office for Africa.

Radwan S (2002) Employment and Unemployment in Egypt: Conventional Problems, Unconventional Remedies. Conference of Employment and Unemployment in Egypt. Cairo, Egypt: The Egyptian Center for Economic Studies.

UNICEF (2013) Egypt in Transition: 2013-2017. Egypt Country Programme Available from: http://www.unicef.org/about/execboard/files/Egypt_CPD_prese ntation-2013-2017.pdf.

Visaria P (1998) Unemployment Among Youth in India: Level, Nature and Policy Implications. Institute of Economic Growth, University of Delhi. Employment and Training Department. Geneva: International Labor Office.

World Bank (2009) Shaping the Future-A Long-Term Perspective of People and Job Mobility for the Middle East and North Africa. Washington, DC. 


\section{Appendix}

Table1. Change Rate (\%) of Labor Force, Employment and Unemployment in Egypt, by Gender (2002-2012)

\begin{tabular}{|c|c|c|c|c|c|c|}
\hline Year & Males & Change Rate & Females & Change Rate & Total & Change Rate \\
\hline \multicolumn{7}{|c|}{ Labor Force } \\
\hline 2002 & 155,339 & - & 43,429 & - & 198,768 & - \\
\hline 2003 & 158,387 & 1.96 & 45,209 & 4.10 & 203,596 & 2.43 \\
\hline 2004 & 158,790 & 0.25 & 49,923 & 10.43 & 208,713 & 2.51 \\
\hline 2005 & 170,760 & 7.54 & 50,280 & 0.72 & 221,040 & 5.91 \\
\hline 2006 & 180,810 & 5.89 & 51,250 & 1.93 & 232,060 & 4.99 \\
\hline 2007 & 185,110 & 2.38 & 57,390 & 11.98 & 242,500 & 4.50 \\
\hline 2008 & 191,200 & 3.29 & 55,320 & -3.61 & 246,520 & 1.66 \\
\hline 2009 & 194,100 & 1.52 & 59,430 & 7.43 & 253,530 & 2.84 \\
\hline 2010 & 201,400 & 3.76 & 60,400 & 1.63 & 261,800 & 3.26 \\
\hline 2011 & 205,406 & 1.99 & 59,884 & -0.85 & 265,290 & 1.33 \\
\hline 2012 & 208,736 & 1.62 & 61,469 & 2.65 & 270,205 & 1.85 \\
\hline \multicolumn{7}{|c|}{ Employment } \\
\hline 2002 & 145,507 & - & 33,055 & - & 178,562 & - \\
\hline 2003 & 146,520 & 0.70 & 34,669 & 4.88 & 181,189 & 1.47 \\
\hline 2004 & 149,364 & 1.94 & 37,810 & 9.06 & 187,174 & 3.30 \\
\hline 2005 & 158,820 & 6.33 & 37,720 & -0.24 & 196,540 & 5.00 \\
\hline 2006 & 168,730 & 6.24 & 38,980 & 3.34 & 207,710 & 5.68 \\
\hline 2007 & 174,330 & 3.32 & 46,820 & 20.11 & 221,150 & 6.47 \\
\hline 2008 & 180,420 & 3.49 & 44,660 & -4.61 & 225,080 & 1.78 \\
\hline 2009 & 183,970 & 1.97 & 45,780 & 2.51 & 229,750 & 2.07 \\
\hline 2010 & 191,530 & 4.11 & 46,760 & 2.14 & 238,290 & 3.72 \\
\hline 2011 & 187,187 & -2.27 & 46,272 & -1.04 & 233,459 & -2.03 \\
\hline 2012 & 189,319 & 1.14 & 46,638 & 0.79 & 235,957 & 1.07 \\
\hline \multicolumn{7}{|c|}{ Unemployment } \\
\hline 2002 & 9,832 & - & 10,374 & - & 20,206 & - \\
\hline 2003 & 11,867 & 20.70 & 10,540 & 1.60 & 22,407 & 10.89 \\
\hline 2004 & 9,426 & -20.57 & 12,113 & 14.92 & 21,539 & -3.87 \\
\hline 2005 & 11,940 & 26.67 & 12,560 & 3.69 & 24,500 & 13.75 \\
\hline 2006 & 12,080 & 1.17 & 12,270 & -2.31 & 24,350 & -0.61 \\
\hline 2007 & 10,780 & -10.76 & 10,570 & -13.85 & 21,350 & -12.32 \\
\hline 2008 & 10,780 & 0.00 & 10,660 & 0.85 & 21,440 & 0.42 \\
\hline 2009 & 10,130 & -6.03 & 13,650 & 28.05 & 23,780 & 10.91 \\
\hline 2010 & 9,870 & -2.57 & 13,640 & -0.07 & 23,510 & -1.14 \\
\hline 2011 & 18,220 & 84.60 & 13,614 & -0.19 & $\mathbf{3 1 , 8 3 4}$ & 35.41 \\
\hline 2012 & 19,417 & 6.57 & 14,831 & 8.94 & 34,248 & 7.58 \\
\hline \multicolumn{7}{|c|}{ Unemployment Rate (\%) } \\
\hline 2002 & 6.33 & - & 23.89 & - & 10.17 & - \\
\hline 2003 & 7.49 & 18.38 & 23.31 & -2.40 & 11.01 & 8.26 \\
\hline 2004 & 5.94 & -20.77 & 24.26 & 4.07 & 10.32 & -6.23 \\
\hline 2005 & 6.99 & 17.79 & 24.98 & 2.95 & 11.20 & 8.53 \\
\hline 2006 & 6.68 & -4.45 & 23.94 & -4.16 & 10.60 & -5.36 \\
\hline 2007 & 5.82 & -12.83 & 18.41 & -23.10 & 8.90 & -16.04 \\
\hline 2008 & 5.64 & -3.19 & 19.27 & 4.67 & 8.70 & -2.28 \\
\hline 2009 & 5.22 & -7.43 & 22.97 & 19.19 & 9.40 & 8.08 \\
\hline 2010 & 4.90 & -6.10 & 22.57 & -1.73 & 9.00 & -4.26 \\
\hline 2011 & 8.87 & 81.00 & 22.73 & 0.73 & 11.99 & 33.22 \\
\hline 2012 & 9.30 & 4.87 & 24.10 & 6.01 & 12.70 & 5.92 \\
\hline
\end{tabular}

Source: CAPMAS 2013. 
Chart 1. Labor Force, Unemployment and Employment in Egypt, 2002-2012

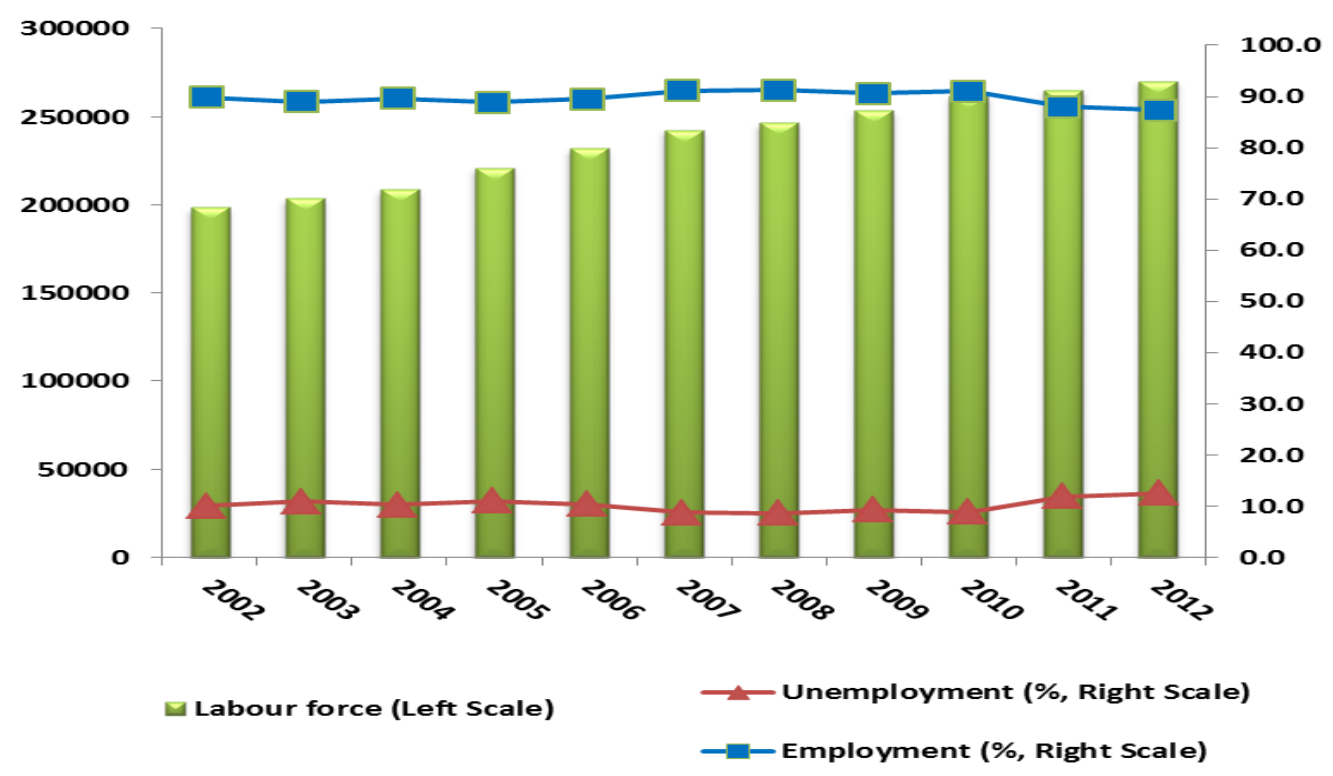

Source: Author's estimations.

Chart 2. Change Rate (\%) of Employed and Unemployed in Egypt, 2002-2012

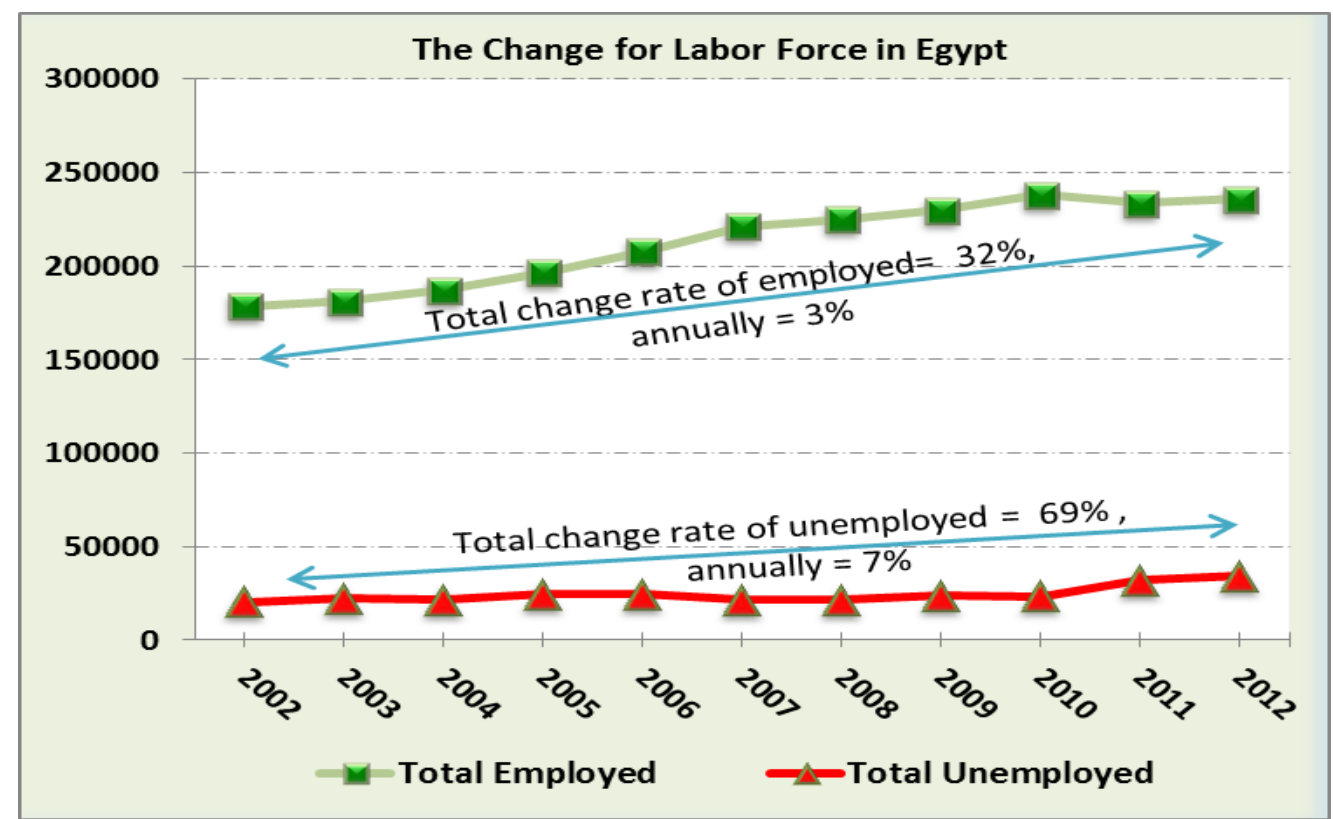

Source: Author's estimations. 
Chart 3. Change Rate (\%) of Females Employed and Unemployed in Egypt, 2002-2012

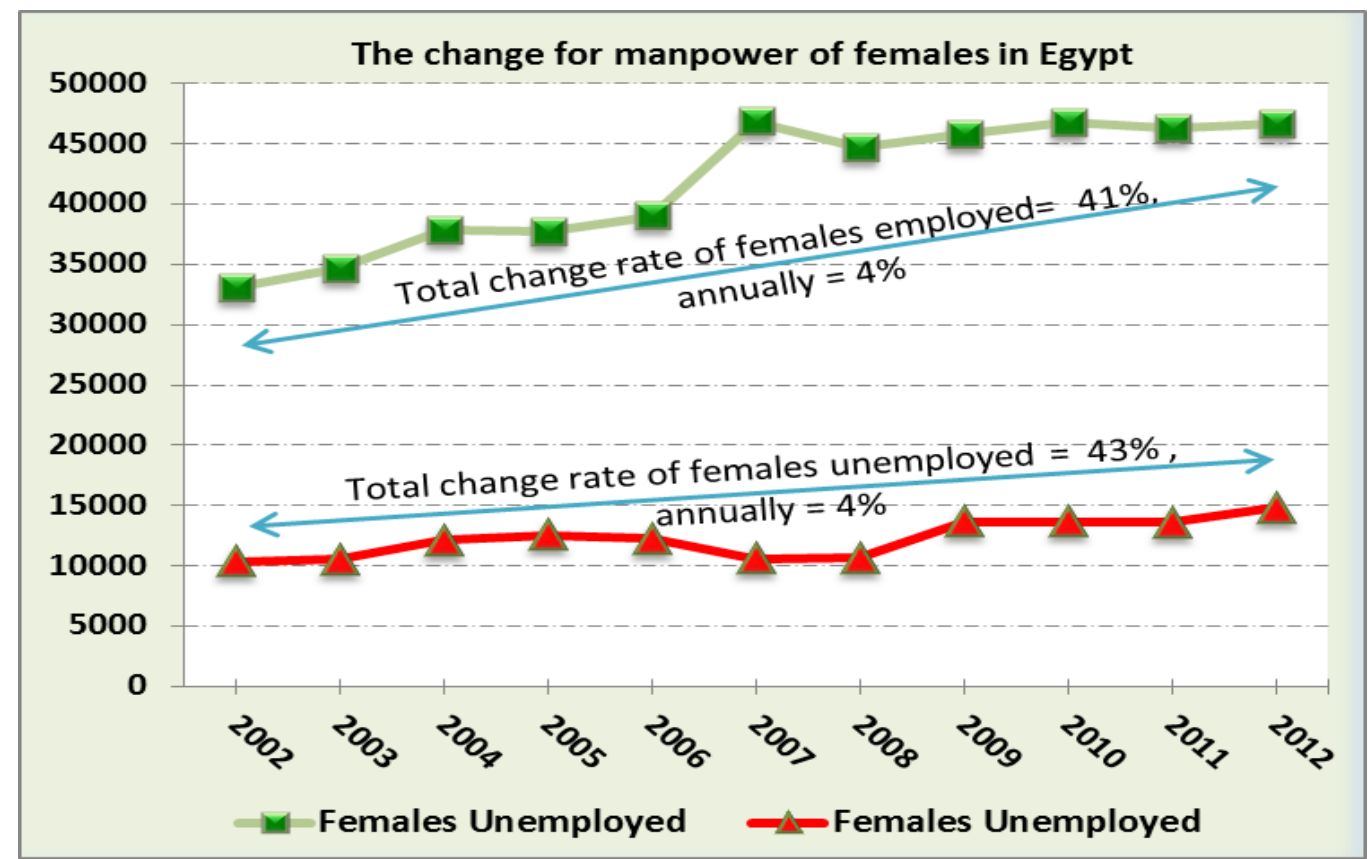

Source: Author's estimations.

Chart 4. Change Rate (\%) of Males Employed \& Unemployed in Egypt, 20022012

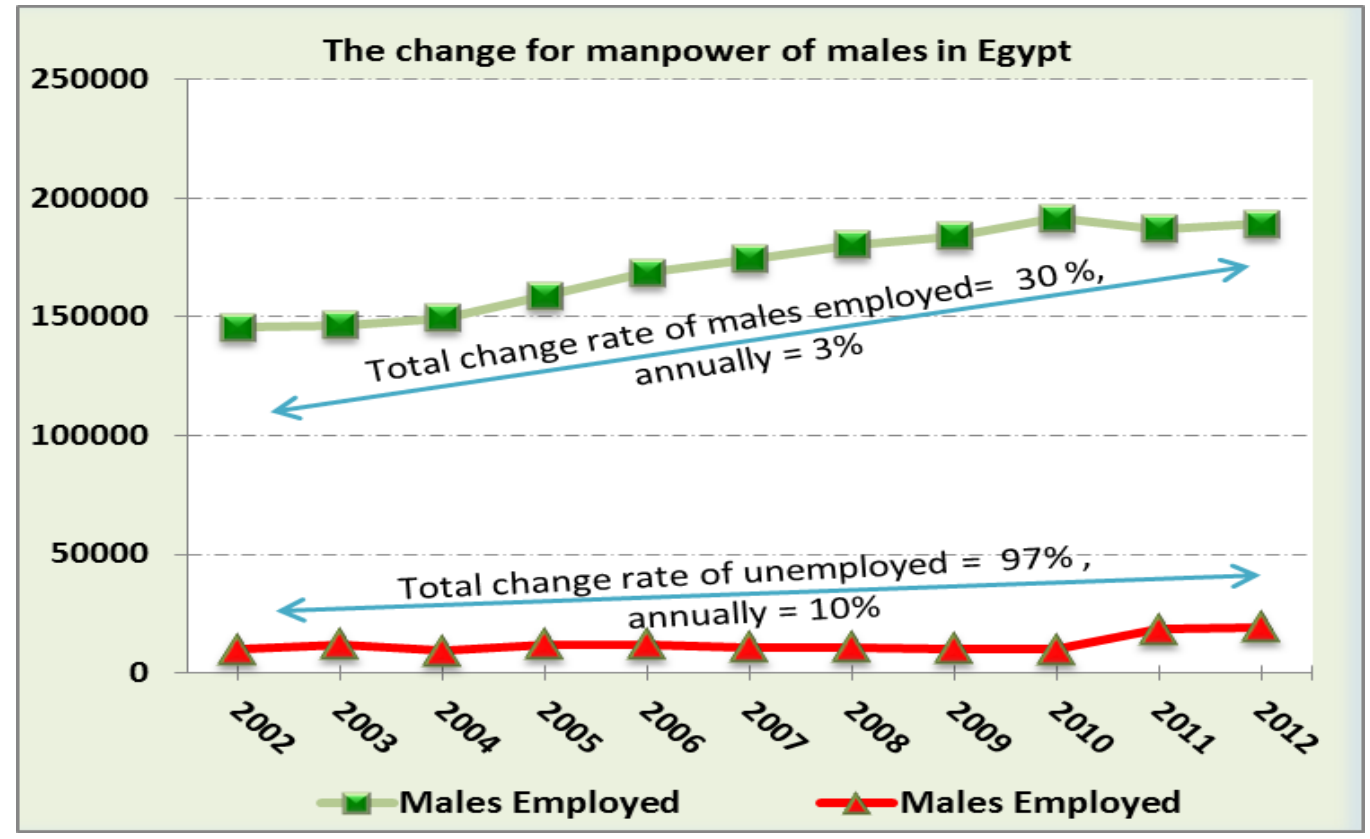

Source: Author's estimations. 
Chart 5. Unemployment Rate in Egypt, by Residence and by Gender, 2012

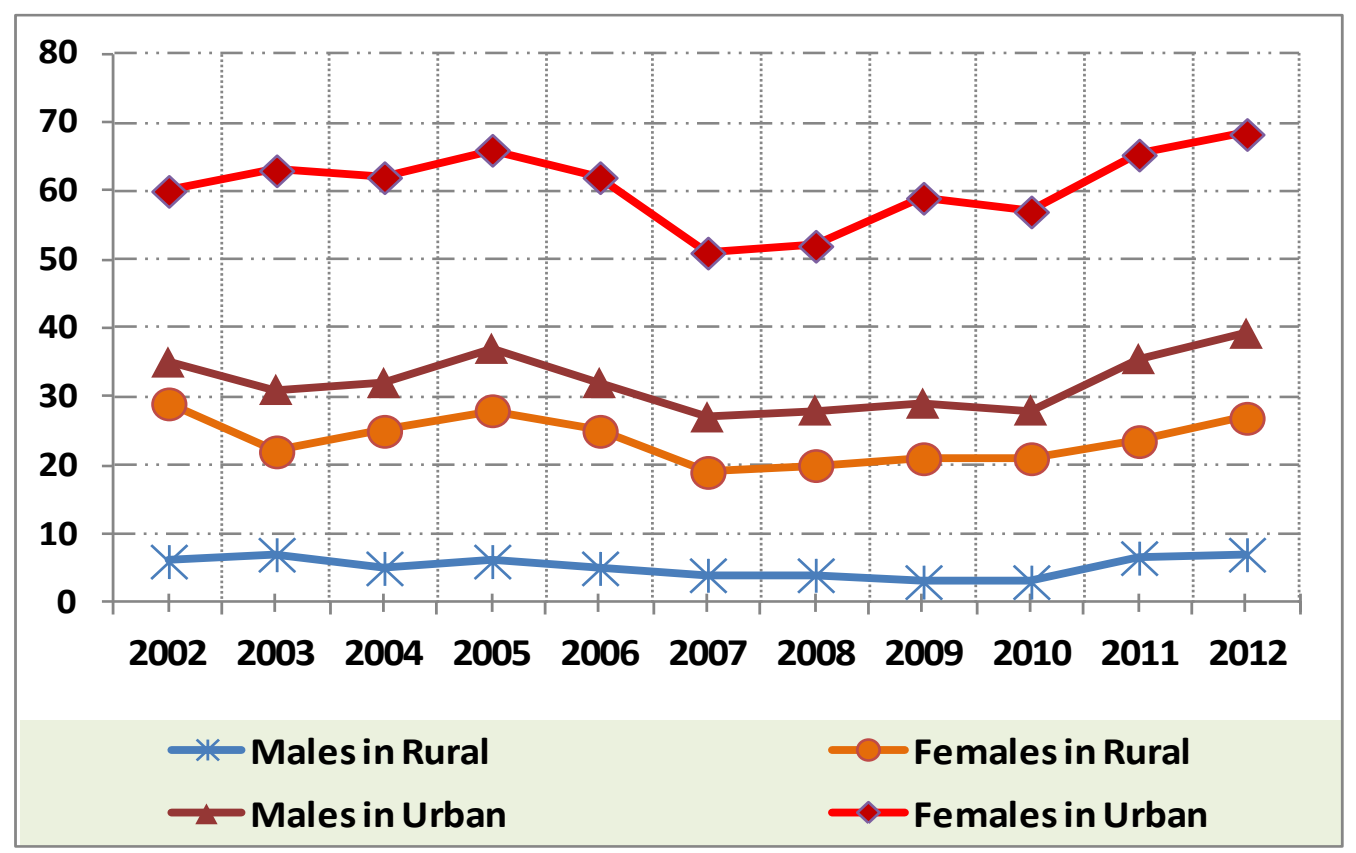

Source: Author's estimations.

Table2. Unemployment Rate in Egypt, by Residence and Gender, 2002-2012

\begin{tabular}{|l|c|c|c|c|c|c|c|c|}
\hline \multirow{2}{*}{ Year } & \multicolumn{9}{|c|}{ Rural } & \multicolumn{4}{c|}{ Urban } \\
\cline { 2 - 9 } & $\begin{array}{c}\text { Males } \\
(\%)\end{array}$ & $\begin{array}{c}\text { Change } \\
\text { rate }(\boldsymbol{\%})\end{array}$ & $\begin{array}{c}\text { Females } \\
(\%)\end{array}$ & $\begin{array}{c}\text { Change } \\
\text { rate (\%) }\end{array}$ & $\begin{array}{c}\text { Males } \\
(\%)\end{array}$ & $\begin{array}{c}\text { Change } \\
\text { rate (\%) }\end{array}$ & $\begin{array}{c}\text { Females } \\
(\%)\end{array}$ & $\begin{array}{c}\text { Change } \\
\text { rate }(\%)\end{array}$ \\
\hline $\mathbf{2 0 0 2}$ & 6 & - & 23 & - & 6 & - & 25 & - \\
\hline $\mathbf{2 0 0 3}$ & 7 & 16.67 & 15 & -34.78 & 9 & 50.00 & 32 & 28.00 \\
\hline $\mathbf{2 0 0 4}$ & 5 & -28.57 & 20 & 33.33 & 7 & -22.22 & 30 & -6.25 \\
\hline $\mathbf{2 0 0 5}$ & 6 & 20.00 & 22 & 10.00 & 9 & 28.57 & 29 & -3.33 \\
\hline $\mathbf{2 0 0 6}$ & 5 & -16.67 & 20 & -9.09 & 7 & -22.22 & 30 & 3.45 \\
\hline $\mathbf{2 0 0 7}$ & 4 & -20.00 & 15 & -25.00 & 8 & 14.29 & 24 & -20.00 \\
\hline $\mathbf{2 0 0 8}$ & 4 & 0.00 & 16 & 6.67 & 8 & 0.00 & 24 & 0.00 \\
\hline $\mathbf{2 0 0 9}$ & 3 & -25.00 & 18 & 12.50 & 8 & 0.00 & 30 & 25.00 \\
\hline $\mathbf{2 0 1 0}$ & 3 & 0.00 & 18 & 0.00 & 7 & -12.50 & 29 & -3.33 \\
\hline $\mathbf{2 0 1 1}$ & 6.5 & 116.67 & 17 & -5.56 & 12 & 71.43 & 29.8 & 2.76 \\
\hline $\mathbf{2 0 1 2}$ & 7 & 7.69 & 19.9 & 17.06 & 12.3 & 2.50 & 29.1 & -2.35 \\
\hline
\end{tabular}

Source: CAPMAS 2013. 
Table 3. Estimates of Employed in Egypt (15+), by Gender and Industry, 2012

\begin{tabular}{|c|c|c|c|c|c|c|c|}
\hline Economic Activity & Males & $\%$ & Females & $\%$ & Total & $\%$ & Z-value \\
\hline $\begin{array}{l}\text { Agriculture, Hunting, } \\
\text { Forestry and Cutting trees }\end{array}$ & 46,333 & 24.47 & 17,522 & 37.57 & 63,855 & 27.06 & $-57.02^{*}$ \\
\hline Mining and Quarrying & 397 & 0.21 & 5 & 0.01 & 402 & 0.17 & $9.33^{*}$ \\
\hline Manufactures & 24,188 & 12.78 & 2,002 & 4.29 & 26,190 & 11.10 & $52.24^{*}$ \\
\hline $\begin{array}{l}\text { Electric, Gas, Steam, Air } \\
\text { condition supply }\end{array}$ & 2,318 & 1.22 & 215 & 0.46 & 2,533 & 1.07 & $14.33^{*}$ \\
\hline $\begin{array}{l}\text { Water support, Drain, } \\
\text { Recycling }\end{array}$ & 1,425 & 0.75 & 164 & 0.35 & 1,589 & 0.67 & $9.49^{*}$ \\
\hline Constructions & 27,765 & 14.67 & 183 & 0.39 & 27,948 & 11.84 & $85.45^{*}$ \\
\hline $\begin{array}{l}\text { Whole and retail sale } \\
\text { vehicles, Motorcycles } \\
\text { repairing }\end{array}$ & 22,623 & 11.95 & 3,225 & 6.91 & 25,848 & 10.95 & $31.18^{*}$ \\
\hline Transportation and storage & 16,125 & 8.52 & 352 & 0.75 & 16,477 & 6.98 & $58.92^{*}$ \\
\hline Food, Residence services & 5,044 & 2.66 & 156 & 0.33 & 5,200 & 2.20 & 30.70* \\
\hline $\begin{array}{l}\text { Information, } \\
\text { Telecommunications }\end{array}$ & 1,632 & 0.86 & 385 & 0.83 & 2,017 & 0.85 & 0.77 \\
\hline $\begin{array}{l}\text { Insurance and Financial } \\
\text { intermediation }\end{array}$ & 1,382 & 0.73 & 571 & 1.22 & 1,953 & 0.83 & $-10.55^{*}$ \\
\hline Real estate, Renting & 151 & 0.08 & 15 & 0.03 & 166 & 0.07 & $3.47^{*}$ \\
\hline $\begin{array}{l}\text { Specialized technical, } \\
\text { Scientific activities }\end{array}$ & 3,208 & 1.69 & 572 & 1.23 & 3,780 & 1.60 & $7.21^{*}$ \\
\hline $\begin{array}{l}\text { Administrative Activities } \\
\text { and Support Services }\end{array}$ & 1,340 & 0.71 & 145 & 0.31 & 1,485 & 0.63 & $9.71^{*}$ \\
\hline $\begin{array}{l}\text { Public Administration , } \\
\text { Defense, Social solidarity }\end{array}$ & 14,132 & 7.46 & 4,749 & 10.18 & 18,881 & 8.00 & $-19.38^{*}$ \\
\hline Education & 11,253 & 5.94 & 11,114 & 23.83 & 22,367 & 9.48 & $118.12^{*}$ \\
\hline Health and Social Work & 2,838 & 1.50 & 3,836 & 8.23 & 6,674 & 2.83 & $-78.48^{*}$ \\
\hline $\begin{array}{l}\text { Amusement and Creation, } \\
\text { Arts Activities }\end{array}$ & 975 & 0.52 & 227 & 0.49 & 1,202 & 0.51 & 0.77 \\
\hline Other Services Activities & 5,297 & 2.80 & 202 & 0.43 & 5,499 & 2.33 & 30.32* \\
\hline $\begin{array}{l}\text { Services of home service } \\
\text { for private households }\end{array}$ & 850 & 0.45 & 988 & 2.12 & 1,838 & 0.78 & $-36.73^{*}$ \\
\hline $\begin{array}{l}\text { International and Regional } \\
\text { Agencies and Organized }\end{array}$ & 24 & 0.01 & 7 & 0.02 & 31 & 0.01 & -0.39 \\
\hline Non classified activities & 19 & 0.01 & 3 & 0.01 & 22 & 0.01 & 0.72 \\
\hline Total & 189,319 & 100 & 46638 & 100 & 235,957 & 100 & \\
\hline
\end{tabular}

* Significant at the level less than 0.05

Source: CAPMAS 2013. 
Table 4. Distribution of Unemployed, Employed in Egypt, by Educational Status and Gender in 2012

\begin{tabular}{|c|c|c|c|c|c|c|c|}
\hline Educational Status & Males & $\%$ & Females & $\%$ & Total & $\%$ & Z-value \\
\hline \multicolumn{8}{|l|}{ Unemployed } \\
\hline Illiterate & 1037 & 5.3 & 65 & 0.4 & 1102 & 3.2 & $25.47^{*}$ \\
\hline Read and Write & 982 & 5.1 & 57 & 0.4 & 1039 & 3.0 & $24.98^{*}$ \\
\hline Lower than Intermediate & 2506 & 12.9 & 462 & 3.1 & 2968 & 8.7 & 31.91* \\
\hline Intermediate & 8701 & 44.8 & 7224 & 48.7 & 15925 & 46.5 & $-7.17^{*}$ \\
\hline $\begin{array}{l}\text { Upper than Intermediate } \\
\text { and Lower than University }\end{array}$ & 957 & 4.9 & 875 & 5.9 & 1832 & 5.3 & $-3.96^{*}$ \\
\hline $\begin{array}{l}\text { University and Above } \\
\text { University }\end{array}$ & 5234 & 27.0 & 6147 & 41.4 & 11381 & 33.2 & $-28.21^{*}$ \\
\hline TOTAL & 19417 & 100.0 & 14830 & 100.0 & 34247 & 100.0 & \\
\hline \multicolumn{8}{|l|}{ Employed } \\
\hline Illiterate & 43381 & 22.9 & 15515 & 33.3 & 58896 & 25.0 & $-46.27^{*}$ \\
\hline Read and Write & 21473 & 11.3 & 1807 & 3.9 & 23280 & 9.9 & $48.44^{*}$ \\
\hline Lower than Intermediate & 24955 & 13.2 & 2088 & 4.5 & 27043 & 11.5 & $52.86^{*}$ \\
\hline Intermediate & 62592 & 33.1 & 11985 & 25.7 & 74577 & 31.6 & $30.64^{*}$ \\
\hline $\begin{array}{l}\text { Upper than Intermediate } \\
\text { and Lower than University }\end{array}$ & 7762 & 4.1 & 2514 & 5.4 & 10276 & 4.4 & $-12.23^{*}$ \\
\hline $\begin{array}{l}\text { University and Above } \\
\text { University }\end{array}$ & 29157 & 15.4 & 12729 & 27.3 & 41886 & 17.8 & $-60.21^{*}$ \\
\hline TOTAL & 189320 & 100 & 46638 & 100 & 235958 & 100 & \\
\hline
\end{tabular}

* Significant at the level less than 0.05 .

Source: CAPMAS 2013.

Table 5. Coefficients ${ }^{(a)}$ of Multiple Regression Analysis for Demographic or Social Variables, 2002-2012

\begin{tabular}{|l|c|c|c|c|c|}
\hline Model & B & S.E & Beta & t & Sig. \\
\hline Constant & -45450.26 & 5801.23 & - & -7.835 & $0.001^{*}$ \\
\hline Births $\left(\mathrm{X}_{1}\right)$ & 11.69 & 1.66 & 0.869 & 7.023 & $0.001^{*}$ \\
\hline Dependency Rate $\left(\mathrm{X}_{9}\right)$ & 372.12 & 44.01 & 0.866 & 8.454 & $0.000^{*}$ \\
\hline$\%$ males unemployed in Urban $\left(\mathrm{X}_{13}\right)$ & 963.99 & 126.42 & 0.491 & 7.626 & $0.001^{*}$ \\
\hline No. of males graduates from Theoretical Faculties $\left(\mathrm{X}_{22}\right.$ & 0.14 & 0.03 & 0.352 & 4.055 & $0.010^{*}$ \\
\hline \multicolumn{2}{|l|}{ F-test for the Model $=91.99^{*}, \mathrm{R}^{2}=0.987$ and Adjusted $\mathrm{R}^{2}=0.976$} \\
\hline
\end{tabular}

Source: Author's estimations.

a. Method: Stepwise.

* Significant at the level less than 0.05.

- Dependent Variable: Number of Unemployed in Egypt.

- The independent variables are presented below:

$\mathrm{X}_{1}$ : Births

$\mathrm{X}_{2}$ : Deaths

$\mathrm{X}_{3}$ : Marriage rates

$\mathrm{X}_{4}$ : Divorce rates

$\mathrm{X}_{5}$ : Natural increase

$\mathrm{X}_{6}$ : Population density

$\mathrm{X}_{7}$ : The population growth rate

$\mathrm{X}_{8}$ : Annual growth of the labor force

$\mathrm{X}_{9}$ : Dependency rate

$\mathrm{X}_{10}$ : \% of women in labor force

$\mathrm{X}_{11}$ :\% of males unemployed in rural

$\mathrm{X}_{12}$ : \% of females unemployed in rural

$\mathrm{X}_{13}$ :\% of males unemployed in urban

$\mathrm{X}_{14}$ : \% of females unemployed in urban 
$\mathrm{X}_{15}$ : Number of students in Theoretical Faculties

$\mathrm{X}_{16}$ : Number of male students in Theoretical Faculties

$\mathrm{X}_{17}$ : Number of female students in Theoretical Faculties

$\mathrm{X}_{18}$ : Number of students in Practical Faculties

$\mathrm{X}_{19}$ : Number of male students in Practical Faculties

$\mathrm{X}_{20}$ : Number of female students in Practical Faculties

$\mathrm{X}_{21}$ : Number of graduates from Theoretical Faculties

$\mathrm{X}_{22}$ : Number of male graduates from Theoretical Faculties

$\mathrm{X}_{23}$ : Number of female graduates from Theoretical Faculties

$\mathrm{X}_{24}$ : Number of graduates from Practical Faculties

$\mathrm{X}_{25}$ : Number of male graduates from Practical Faculties

$\mathrm{X}_{26}$ : Number of female graduates from Practical Faculties

$\mathrm{X}_{27}$ : Number of students in Technical education

$\mathrm{X}_{28}$ : Number of male students in Technical education

$\mathrm{X}_{29}$ : Number of female students in Technical education

Chart 6. The Percenrage of Employed and Unemployed in Egypt, by Educational Status and Gender, 2012

\begin{tabular}{|c|c|c|c|c|c|c|}
\hline \multicolumn{3}{|c|}{ Males } & & \multicolumn{3}{|c|}{ Females } \\
\hline 1 & $84.8 \%$ & $15.2 \%$ & $\begin{array}{c}\text { University \& Above } \\
\text { University }\end{array}$ & $32.6 \%$ & $67.4 \%$ & \\
\hline 1 & $89.0 \%$ & $11.0 \%$ & $\begin{array}{l}\text { Upper than Intermediate \& } \\
\text { Lower than University }\end{array}$ & $25.8 \%$ & $74.2 \%$ & \\
\hline I & $87.8 \%$ & $12.2 \%$ & Intermediate & $37.6 \%$ & $62.4 \%$ & \\
\hline I & $90.9 \%$ & $9.1 \%$ & Lower than Intermediate & $18.1 \% \mid$ & $81.9 \%$ & \\
\hline I & $95.6 \%$ & $4.4 \%$ & Read \& Write & $3.1 \%$ & $96.9 \%$ & \\
\hline I & $97.7 \%$ & $\begin{array}{r}2.3 \% \\
4\end{array}$ & Illiterate & $0.4 \%$ & $99.6 \%$ & \\
\hline $100 \%$ & $50 \%$ & $0 \%$ & $\begin{array}{l}\text { Unemployed } \\
\text { 口 Employed }\end{array}$ & $0 \%$ & $50 \%$ & $100 \%$ \\
\hline
\end{tabular}

Source: Author's estimations. 